\title{
High prevalence of hypertriglyceridaemia and apolipoprotein abnormalities in coronary artery disease
}

\author{
M BARBIR, D WILE, I TRAYNER, V R ABER, G R THOMPSON \\ From the Departments of Medicine, Chemical Pathology, Medical Physics, and Medical Research Council \\ Lipoprotein Team, Royal Postgraduate Medical School, Hammersmith Hospital, London
}

SUMMARY Serum lipids and apolipoproteins A-I and B were measured in 174 men aged $<60$ with angiographically confirmed coronary artery disease and in $\mathbf{5 7 2}$ healthy control men. Two thirds of the patients had raised age-corrected values of fasting serum cholesterol and/or triglyceride and/or a low high density lipoprotein (HDL) cholesterol compared with the controls. Eighteen (30\%) of the 61 normolipidaemic patients had a concentration of serum apolipoprotein A-I below the 5th percentile of 233 controls. In normolipidaemic patients on $\beta$ blockers the relative prevalence of serum low density lipoprotein (LDL)-apolipoprotein B values above the 95th percentile of 339 controls was significantly increased. Discriminant function analysis showed that a raised concentration of serum triglyceride was the best discriminant between patients and controls, with raised LDL-apolipoprotein B and reduced apolipoprotein A-I coming second only to triglyceride in analyses where each was separately compared with all the lipid variables. These associations were highly significant and were independent of other influences, including $\beta$ blockade.

These findings re-emphasise the importance of hypertriglyceridaemia as a risk factor and confirm that apolipoprotein abnormalities occur frequently in coronary disease, even in normolipidaemic patients.

Evidence that serum apolipoprotein measurements are useful indices of the risk of coronary heart disease was reviewed four years ago $^{12}$ and several reports have since' appeared which further substantiate this concept. $^{3-9}$ Opinions are divided, however, as to whether increases in apolipoprotein B, the protein moiety of low density lipoprotein (LDL), or decreases in apolipoprotein A-I, the major protein of high density lipoprotein (HDL), correlate any better with angiographically defined coronary artery disease than do increases in LDL cholesterol or decreases in HDL cholesterol. $\rightarrow 9$

The object of the present study was to assess the value of apolipoprotein measurements as risk factors by investigating the frequency of serum lipid abnormalities in medically treated patients with angiographically confirmed coronary artery disease and by determining how often apolipoprotein abnormalities

Requests for reprints to Dr G R Thompson, MRC Lipoprotein Team, Hammersmith Hospital, Ducane Road, London W12 ONN.

Accepted for publication 11 July 1988 occurred, especially in those patients found to be normolipidaemic.

\section{Patients and methods}

During the period June 1985-July 1986 all men below the age of 60 admitted to Hammersmith Hospital to undergo diagnostic coronary angiography or coronary artery bypass grafting had blood taken on the morning before these procedures, after an overnight fast, for measurement of serum lipids and apolipoproteins. Patients with diabetes, those on lipid lowering agents, and those who had already undergone coronary artery bypass grafting or had had a myocardial infarct within the preceding two months were excluded, as were those in whom the angiogram did not show significant coronary artery disease, defined as luminal stenosis of $>50 \%$ in at least one vessel. Concentrations of serum total cholesterol and triglyceride were analysed enzymatically (Technicon Auto Analyzer methods SE4-0039 PE and SE-0065 FBI), as was serum HDL cholesterol after precipitation with heparin-manga- 
nese. ${ }^{10}$ The concentration of LDL cholesterol was calculated by the formula of Friedewald et $a l^{11}$ except in patients with triglyceride values of $4.5 \mathrm{mmol} / 1$, in whom LDL cholesterol was measured after ultracentrifugation of serum. ${ }^{12}$ Serum apolipoprotein A-I was measured by an immunoturbidometric method (Orion Diagnostica, marketed in the United Kingdom by Oxoid, Basingstoke, Hampshire) and LDLapolipoprotein B by radial immunodiffusion, as originally described by Sniderman et $a l^{13}$ and modified by Havekes et al. ${ }^{14}$ Results were complete for 174 of the 188 consecutive patients who originally qualified for this survey.

Control values for fasting serum lipids and apolipoproteins were derived from symptom free men aged $20-60$ with normal electrocardiograms who had undergone health screening at the British United Provident Association Medical Centre (BUPA), London between March 1983 and July 1986. Serum was obtained from 339 men for determination of LDL-apolipoprotein $B$ and subsequently from another 233 men for determination of apolipoprotein A-I. Measurement of LDL-apolipoprotein B in patients with coronary artery disease and in controls was always performed by IT and apolipoprotein A-I was measured by $D W$. In all the controls, enzymatic analysis of total cholesterol, triglyceride, and HDL cholesterol (the last after dextran sulphate-magnesium precipitation) ${ }^{15}$ was performed by JS Pathology Services on a Technicon SMAC System similar to that used at Hammersmith Hospital. To correct for interlaboratory differences multiple split sample assays were performed over a wide range of concentrations in each laboratory and conversion factors derived from these comparisons were used to make the Hammersmith Hospital values compatible with JS Pathology Services values.

There were no significant differences between the two control groups-their mean values of age, serum lipids, and lipoproteins being almost identical (table 1). These were therefore combined into one control group of $\mathbf{5 7 2}$ men for all case-control comparisons except those for apolipoprotein values. Because the patients with coronary artery disease were on average older than the controls (mean (SD) age of patients $50.4(6.7) v$ mean age of controls $43.9(8.5)$ ) all lipid, lipoprotein, and apolipoprotein values were adjusted to the age of 45 by linear regressions techniques. Triglyceride values were $\log$ transformed before statistical analysis but untransformed values are given in the text and tables.

Statistical comparisons were undertaken with the aid of the NWA StatPak (Multifunction Statistics Library, Version 3.1, Northwest Analytical, Portland, Oregon) and SPSS/PC+ (SPSS, Chicago, Illinois). Discriminant function analysis was perfor-
Table 1 Serum lipids in the two subgroups of controls (mean (SD))

\begin{tabular}{|c|c|c|}
\hline & Apo A-I controls & Apo $B$ controls \\
\hline Variable & $(n=233)$ & $(n=339)$ \\
\hline $\begin{array}{l}\text { Age }(\mathrm{yr}) \\
\text { Total cholesterol }(\mathrm{mmol} / \mathrm{l}) \\
\text { Triglyceride }(\mathrm{mmol} / \mathrm{l}) \\
\text { HDL cholesterol }(\mathrm{mmol} / \mathrm{l}) \\
\text { LDL cholesterol (mmol/l) }\end{array}$ & $\begin{array}{l}44(8) \\
6 \cdot 16(1 \cdot 10) \\
1.40(0.74) \\
1.25(0.30) \\
4 \cdot 27(1.05)\end{array}$ & $\begin{array}{l}44(9) \\
6.13(1.05) \\
1.39(0.70) \\
1.21(0.29) \\
4.29(1.00)\end{array}$ \\
\hline
\end{tabular}

Apo A-I, apolipoprotein A-I; Apo B, apolipoprotein B.

med with BMDP statistical software (University of California Press, Berkeley, California).

\section{Results}

In the 174 patients with coronary artery disease the mean values of total cholesterol, triglyceride, and LDL cholesterol were higher, and those of HDL cholesterol were lower, than in the 572 controls ( $p<0.01$ for each pair of variables) (table 2). Apolipoprotein A-I values were lower and LDLapolipoprotein B values were higher in patients with coronary artery disease than in their respective subgroups of controls ( $p<0.001$ in each instance). Figures 1-4 show the frequency distributions of concentrations of serum lipids and lipoproteins in patients with coronary artery disease and in controls; the distribution of triglycerides was positively skewed. High values of total cholesterol, triglyceride, and LDL cholesterol and low values of HDL cholesterol were more common in patients than in controls.

Figures 5 and 6 show the frequency distributions of the values for serum apolipoprotein A-I and LDLapolipoprotein B in patients with coronary artery disease and the corresponding controls. Patients with coronary artery disease had a higher frequency of

Table 2 Concentrations (mean (SD)) of serum lipid, lipoprotein, and apoprotein in patients with coronary artery disease and in controls

\begin{tabular}{|c|c|c|c|c|}
\hline Variable & $\begin{array}{l}\text { Patients } \\
(n=174)\end{array}$ & $\begin{array}{l}\text { Controls } \\
(n=572)\end{array}$ & $t$ & $p$ \\
\hline \multirow{6}{*}{$\begin{array}{l}\text { Total cholesterol } \\
\text { (mmol/l) } \\
\text { Triglyceride } \\
\text { (mmol/l) } \\
\text { Log }_{10} \text { triglyceride } \\
\text { (mmol/l) } \\
\text { HDL cholesterol } \\
\text { (mmol/1) } \\
\text { LDL cholesterol } \\
\text { (mmol/1) } \\
\text { Apo A-I (mg/dl) } \\
\text { LDL-apo B (mg/ } \\
\text { dl) }\end{array}$} & $6.66(1.34)$ & $6.14(1.07)$ & $5 \cdot 27$ & $<0.001$ \\
\hline & $2.43(1.37)$ & $1.40(0.71)$ & - & ene \\
\hline & $0.34(0.20)$ & $0.10(0.20)$ & $13 \cdot 56$ & $<0.001$ \\
\hline & $0.98(0.29)$ & $1.22(0.29)$ & $-9 \cdot 70$ & $<0.001$ \\
\hline & $\begin{array}{l}4.54(1.05) \\
126(23)\end{array}$ & $\begin{array}{r}4 \cdot 28(1.01) \\
145(22)^{\star}\end{array}$ & $\begin{array}{r}2 \cdot 87 \\
-8 \cdot 49\end{array}$ & $\begin{array}{l}<0.004 \\
<0.001\end{array}$ \\
\hline & $137(38)$ & $113(26) \dagger$ & $8 \cdot 26$ & $<0.001$ \\
\hline
\end{tabular}




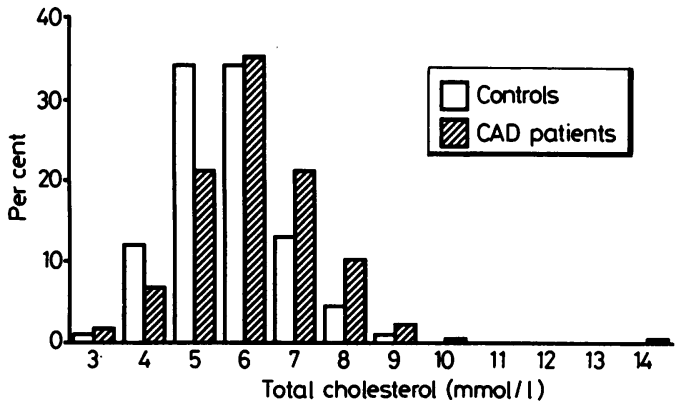

Fig 1 Frequency distributions of serum total cholesterol in controls $(n=572)$ and patients with coronary artery disease $(C A D)(n=174)$.

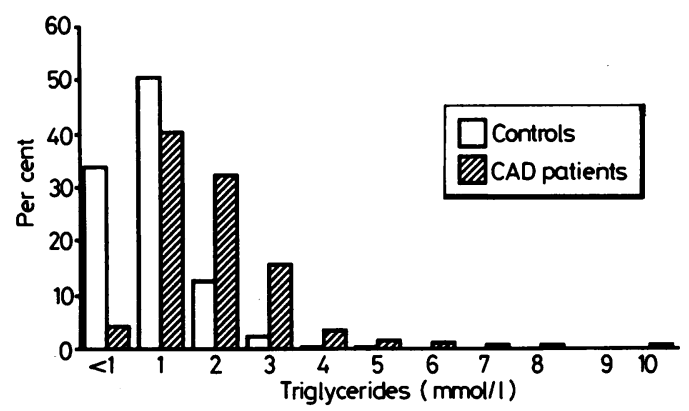

Fig 2 Frequency distributions of serum triglyceride in controls and patients with coronary artery disease.

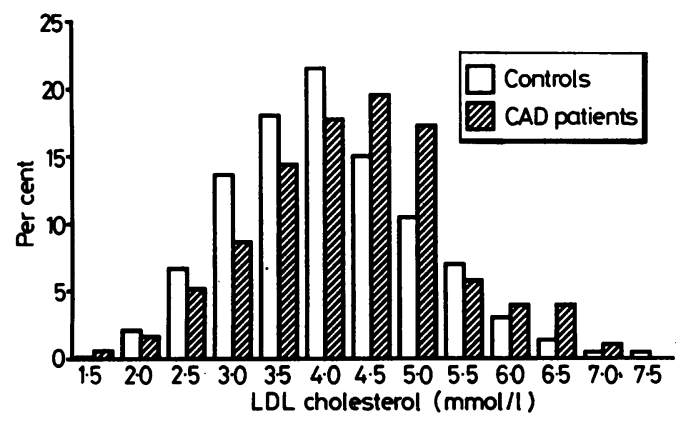

Fig 3 Frequency distributions of $L D L$ cholesterol in controls and patients with coronary artery disease.

high LDL-apolipoprotein $B$ values and low apolipoprotein $\mathrm{A}-\mathrm{I}$ values than the controls, with less overlap between the two groups than was evident for LDL and HDL cholesterol (figs 3 and 4).

Table 3 shows the proportion of patients and controls with abnormal values of each measurement. For total cholesterol we used a cut off value of $6.7 \mathrm{mmol} / 1$, which was the arbitrary upper limit of normal at the BUPA Medical Centre. For all the

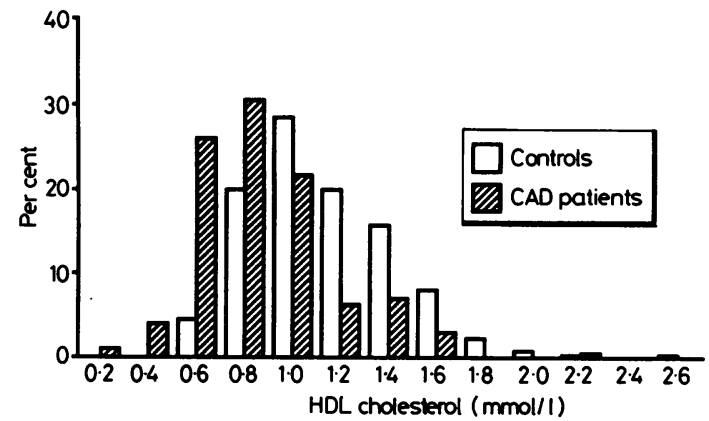

Fig 4 Frequency distributions of HDL cholesterol in controls and patients with coronary artery disease.

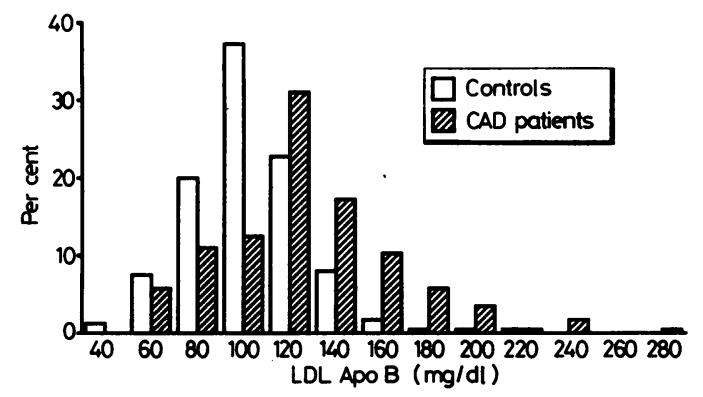

Fig 5 Frequency distributions of $L D L$-apolipoprotein $B$ in controls $(n=339)$ and patients with coronary artery disease.

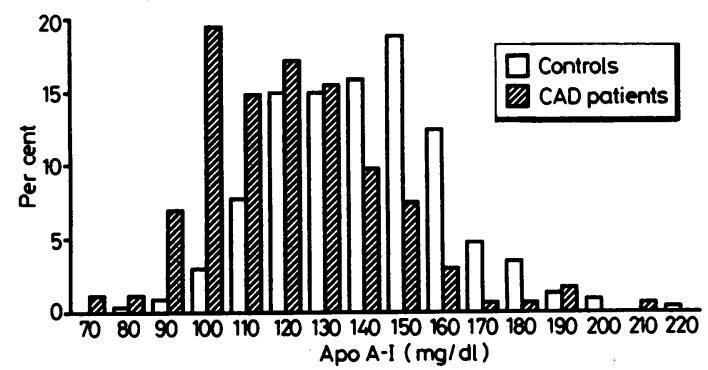

Fig 6 Frequency distributions of apolipoprotein $A-I$ in controls $(n=233)$ and patients with coronary artery disease.

other variables, the 95th percentile or, for HDL cholesterol and apolipoprotein A-I, the 5th percentile values of the controls were used to define abnormality. The final column of this table gives the ratio or relative prevalence of an abnormal value in patients with coronary artery disease compared with controls and the $95 \%$ confidence intervals. Relative prevalence values were lowest with total cholesterol (1.59) and LDL cholesterol (1.64); LDL cholesterol 
Table 3 Proportions of abnormal values in patients and controls

\begin{tabular}{|c|c|c|c|}
\hline Value & $\begin{array}{l}\text { Patients } \\
(\%)\end{array}$ & $\begin{array}{l}\text { Controls } \\
(\%)\end{array}$ & $\begin{array}{l}\text { Relative } \\
\text { prevalence } \\
\text { (95\% confidence } \\
\text { interval) }\end{array}$ \\
\hline $\begin{array}{l}\text { Total cholesterol } \\
>6.7 \mathrm{mmol} / 1 \\
\text { Triglyceride } \\
>2.78 \mathrm{mmol} / 1 \\
\text { HDL cholesterol } \\
<0.80 \mathrm{mmol} / 1 \\
\text { LDL cholesterol } \\
>6.05 \mathrm{mmol} / 1 \\
\text { Apolipoprotein A-I } \\
<110 \mathrm{mg} / \mathrm{dl} \\
\text { LDL apolipoprotein B } \\
>153 \mathrm{mg} / \mathrm{dl}\end{array}$ & $\begin{array}{r}42.0 \\
29.9 \\
31.0 \\
8.0 \\
29.3 \\
26.4\end{array}$ & $\begin{array}{r}26.4 \\
4.9 \\
4.9 \\
4.9 \\
4.7 \\
4.7\end{array}$ & $\begin{array}{l}1 \cdot 59^{\star} \\
(1 \cdot 27-1 \cdot 99) \\
6 \cdot 11^{\star} \\
(3 \cdot 99-9 \cdot 36) \\
6 \cdot 34^{\star} \\
(4 \cdot 15-9.69) \\
1 \cdot 64 \\
(0 \cdot 88-3 \cdot 04) \\
6 \cdot 21^{\star} \\
(3 \cdot 34-11 \cdot 56) \\
5 \cdot 60^{\star} \\
(3 \cdot 27-9.60)\end{array}$ \\
\hline
\end{tabular}

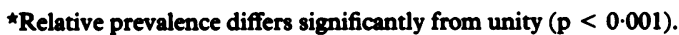

did not differ significantly from unity. In contrast, abnormal values of triglyceride, HDL cholesterol, and each of the apolipoproteins were approximately six times more common in patients than in controls ( $p<0.001$ in each instance).

\section{FREQUENCY OF ABNORMAL APOLIPOPROTEIN VALUES IN NORMOLIPIDAEMIC PATIENTS}

In those individuals with both normal total cholesterol and normal triglyceride $(48 \%$ of the patients and $71 \%$ of controls) the relative prevalence of a low HDL cholesterol was 5.96 (95\% confidence interval 3.35 - 10.61). None of these subjects had a raised LDL cholesterol value. Thirty five per cent of the patients with coronary artery disease and $68 \%$ of controls were normolipidaemic-that is they had normal concentrations of total cholesterol, triglyceride, HDL cholesterol, and LDL cholesterol. Table 4 shows the relative prevalence of apolipoprotein abnormalities in these normolipidaemic individuals. The relative prevalence of a low apolipoprotein A-I was significantly increased whereas that of a raised LDL-apolipoprotein $B$ just failed to reach significance. The relative prevalence of a raised concentration of LDL-apolipoprotein B seemed to be higher in type IV individuals (raised triglyceride and normal LDL cholesterol) at 5.32 (0.78 - 36.35), but again this increase was not statistically significant.

\section{CLINICAL CHARACTERISTICS OF PATIENTS WITH CORONARY ARTERY DISEASE}

Serum lipid and apolipoprotein values in patients with coronary artery disease were similar irrespective of whether patients were admitted for angiography or coronary artery bypass grafting, presence or absence of previous myocardial infarction, and whether or not they were European. Table 5 shows the frequency of these and other characteristics. The lack
Table 4 Proportions of abnormal apoprotein values in normolipidaemic patients and controls

\begin{tabular}{llll}
\hline Variable & $\begin{array}{l}\text { Patients } \\
(\%)\end{array}$ & $\begin{array}{l}\text { Relative } \\
(\%)\end{array}$ & $\begin{array}{l}\text { Controls } \\
\text { prevalence } \\
(95 \% \text { confidence } \\
\text { interval) }\end{array}$ \\
\hline $\begin{array}{l}\text { Apolipoprotein A-I } \\
\begin{array}{l}\text { <110 mg/dl } \\
\text { LD apolipoprotein B } \\
>153 \mathrm{mg} / \mathrm{dl}\end{array}\end{array}$ & 29.5 & 5.6 & $\begin{array}{l}5.31 * \\
(2.52-11 \cdot 17)\end{array}$ \\
\hline
\end{tabular}

«Relative prevalence differs significantly from unity ( $<<0.001$ ).

Table 5 Clinical characteristics of patients

\begin{tabular}{lrr}
\hline Characteristic & No & $\%$ \\
\hline Admitted for CABG & 47 & 27 \\
Previous MI & 103 & 59 \\
European & 140 & 80 \\
On $\beta$ blockers & 113 & 65 \\
Family history of CHD & 99 & 57 \\
Cigarette smoking & 74 & 43 \\
Hypertension & 33 & 19 \\
Tendon xanthomas & 3 & 2 \\
\hline
\end{tabular}

CABG, coronary artery bypass grafting; CHD, coronary heart disease; MI, myocardial infarction.

Smokers currently smoked $>10$ cigarettes/day or had given up less than a year before.

Hypertension was defined as a diastolic pressure $>100 \mathrm{~mm} \mathrm{Hg}$.

of any racial difference in the concentraton of serum lipids is striking since only $7 \%$ of the controls were not European, whereas $20 \%$ of the patients with coronary artery disease were immigrants, generally from the Indian subcontinent. There was a family history of coronary heart disease in $57 \%$ of the patients with coronary artery disease, of whom three $(2 \%)$ had tendon xanthomas, which are indicative of familial hypercholesterolaemia.

Treatment with $\beta$ blockers was an important determinant of concentrations of HDL cholesterol and apolipoprotein A-I. Mean values (SD) were lower in the $65 \%$ of patients on these drugs $(0.93$ $(0.27) \mathrm{mmol} / \mathrm{l}$ and $123(23) \mathrm{mg} / \mathrm{dl}$ ) than in those not taking them $(1.06(0.31) \mathrm{mmol} / 1$ and $130(24) \mathrm{mg} / \mathrm{dl})$, the difference in HDL cholesterol being significant at the $1 \%$ level. The effect of these drugs on triglycerides was less pronounced, with mean values in the two groups not differing significantly $(2.56$ $(1.44)$ versus $2.20(1.21) \mathrm{mmol} / \mathrm{l})$, and this was also true of their effect on LDL-apolipoprotein B (139 (40) versus $132(43) \mathrm{mg} / \mathrm{dl})$. The relative prevalence of a raised LDL-apolipoprotein B was significantly increased in normolipidaemic patients, but only if they were on $\beta$ blockers $(5.27$ with $95 \%$ confidence limits of 1.24 to $22.47, p<0.05$ ).

Examination of the relation between smoking and concentrations of apolipoproteins A-I showed that mean values were lower $(122(20) \mathrm{mg} / \mathrm{dl})$ in the 74 
smokers than in the 100 non-smokers $(128(25) \mathrm{mg} /$ dl), but this difference was not statistically significant. The mean value in the subgroup of 36 nonsmokers not on $\beta$ blockers was higher (132 (26) $\mathrm{mg} /$ dl) but it was still significantly lower than the mean value in controls $(145(22) \mathrm{mg} / \mathrm{dl}, \mathrm{p}<0.002)$. This suggests that the low concentration of apolipoprotein A-I in patients with coronary artery disease was accentuated by, but not wholly attributable to, smoking and $\beta$ blockade.

\section{DISCRIMINANT FUNCTION ANALYSIS}

Stepwise discriminant function analysis was performed, after log transformation in the case of triglycerides, as follows: (a) all lipid variables in all patients and controls; $(b)$ all lipid variables and LDLapolipoprotein $B$ in all patients and the apolipoprotein B subgroup of controls; $(c)$ all lipid variables and apolipoprotein A-I in all patients and the apolipoprotein A-I subgroup of controls.

In addition, each of the three analyses was performed separately on patients grouped according to whether they were $(n=113)$ or were not $(n=61)$ receiving $\beta$ blockers. The results, shown in Table 6 , indicate that triglyceride was the best discriminant between patients and controls, irrespective of $\beta$ blockers, and that of the lipid variables HDL cholesterol was the next best discriminator. LDLapolipoprotein B displaced HDL-cholesterol to third place whereas apolipoprotein A-I eliminated it altogether in analyses in which each apolipoprotein was evaluated separately against the lipid variables. However, the design of the study did not permit a comparison of LDL-apolipoprotein B versus apolipoprotein A-I. Total cholesterol was an independent variable only in patients not on $\beta$ blockers.

\section{Discussion}

All case-control studies are by their nature opportunistic and therefore liable to unavoidable biases, unlike

Table 6 Variables contributing independently to the discrimination between patients and controls ranked in order of importance ( $p<0.001$ in every instance)

\begin{tabular}{|c|c|c|c|}
\hline Analysis & All subjects & No $\beta$ blockers & $\beta$ blockers \\
\hline All lipids & $\begin{array}{l}\text { (a) TG } \\
\text { (b) HDL-C }\end{array}$ & $\begin{array}{l}\text { (a) TG } \\
\text { (b) HDL-C } \\
\text { (c) TC }\end{array}$ & $\begin{array}{l}\text { (a) TG } \\
\text { (b) HDL-C }\end{array}$ \\
\hline $\begin{array}{l}\text { All lipids plus } \\
\text { LDL-apo B }\end{array}$ & $\begin{array}{l}\text { (a) TG } \\
\text { (b) LDL-apo } \\
\text { (c) HDL-C }\end{array}$ & $\begin{array}{l}\text { (a) TG } \\
\text { B (b) LDL-apo B }\end{array}$ & $\begin{array}{l}\text { (a) TG } \\
3 \text { (b) LDL-apo B } \\
\text { (c) HDL-C }\end{array}$ \\
\hline $\begin{array}{l}\text { All lipids plus } \\
\text { apo A-I }\end{array}$ & $\begin{array}{l}\text { (a) TG } \\
\text { (b) apo A-I }\end{array}$ & $\begin{array}{l}\text { (a) TG } \\
\text { (b) apo A-I }\end{array}$ & $\begin{array}{l}\text { (a) TG } \\
\text { (b) apo A-I }\end{array}$ \\
\hline
\end{tabular}

TG, triglyceride; TC, total cholesterol.

See text and footnote to table 1 for other abbreviations. prospective surveys. Although this study is no exception it does give an impression of the pattern of risk factors present in men with newly diagnosed, symptomatic coronary disease in a routine clinical setting. Of the 174 patients with angiographically confirmed coronary artery disease just under $60 \%(104)$ had had a previous myocardial infarct. None had yet undergone any intervention other than treatment with antianginal drugs but $27 \%$ (47) were about to undergo coronary artery bypass grafting. Almost two thirds of the patients were on $\beta$ blockers. The controls, who were drawn from men who had attended the BUPA Medical Centre for health screening during the previous three years, were free from symptoms or electrocardiographic evidence of coronary heart disease. Analysis of this group provided the cut off values used to define hyperlipidaemia and abnormally low concentrations of HDL cholesterol in patients with coronary artery disease and provided reference values for apolipoprotein A-I and LDLapolipoprotein B. Despite possible differences in social class, occupation, and dietary habits the distribution of serum cholesterol concentrations in men attending the BUPA Medical Centre in London is known to be similar to that of men screened during the British Regional Heart Study, ${ }^{16}$ who were chosen as being representative of the population at large.

Serum concentrations of cholesterol and triglyceride in fasting patients and controls were measured in different laboratories by similar enzymatic methods. Two methods of precipitation were used to assay HDL cholesterol but the dextran sulphate-magnesium method used to analyse samples from controls gives results that are almost identical with the modified heparin-manganese method used in the patients. ${ }^{17}$ Interlaboratory differences were minimised by applying appropriate correction factors. Apolipoprotein A-I and LDLapolipoprotein $B$ were always measured by the same operators, but on separate control groups. The validity of the radial immunodiffusion method used to assay LDL-apolipoprotein B was confirmed recently ${ }^{18}$ and the immunoturbidometric method of measuring apolipoprotein A-I gives similar results to radial immunodiffusion ${ }^{19}$ (E Bevan and I Trayner, unpublished).

Concentrations of serum cholesterol or triglyceride (or both) were increased in $52 \%$ of the patients with coronary artery disease and $29 \%$ of the controls. In the minority of Asian patients concentrations of serum lipids were similar to those in European patients. The finding that hyperlipidaemia was twice as common in patients with coronary artery disease accords with earlier studies, ${ }^{20-22}$ and reemphasises the importance of blood lipids in promoting atherosclerosis. The strength of the association 
between serum cholesterol and coronary heart disease mortality was underlined recently by the results of a very large prospective study, ${ }^{23}$ which lend support to the earlier recommendations of the Consensus Development Conference on Lowering Blood Cholesterol to Prevent Heart Disease. ${ }^{24}$ This defined $6.7 \mathrm{mmol} / 1$ as the concentration of total cholesterol above which there is a high risk of coronary disease in those aged 40 and over. We and the BUPA Medical Centre used this value rather than the higher 95th percentile value to define hypercholesterolaemia.

The role of triglycerides is more controversial ${ }^{25}$ but in the present study multivariate analysis showed that hypertriglyceridaemia was the most powerful discriminant between controls and patients. This finding accords with the results of the Stockholm prospective study ${ }^{26}$ and with Castelli's recent reappraisal of data from the Framingham Study. ${ }^{27}$

Hypoalphalipoproteinaemia (HDL cholesterol $<5$ th percentile) was also more common in the patients than in the controls ( $31 \%$ versus $5 \%$ respectively), and the odds ratio (six) was identical to that reported by Ordovas et al..$^{28}$ Several prospective studies have found HDL cholesterol to be correlated independently (and negatively) with coronary heart disease, ${ }^{29} 30$ but the British Regional Heart Survey was an exception because HDL cholesterol was not predictive on multivariate analysis. ${ }^{31} 32$

The relative prevalence of abnormally high serum concentrations of apolipoprotein $B$ in patients not taking $\beta$ blockers who had normal LDL cholesterol concentrations was 5.38 (95\% confidence interval $0.72-40.19)$ in those with raised serum triglycerides compared with 1.03 (95\% confidence interval 0.24 4.38) for those with normal triglycerides. Despite the wide confidence interval for the former group, which reflects the small numbers studied, these findings provide additional evidence of a relation between hypertriglyceridaemia and abnormally high serum concentrations of apolipoprotein $B .{ }^{33}$ Raised concentrations of apolipoprotein $B$ have also been reported to correlate with a family history of premature myocardial infarction ${ }^{34}$ and have been seen in the children of such individuals. ${ }^{35}$ This suggests a genetic basis. The increased frequency of raised concentrations of apolipoprotein $B$ in normolipidaemic patients on $\beta$ blockers, which we saw, suggests that this syndrome can also be iatrogenic.

The main new finding in this study was the presence of abnormally low serum concentrations of apolipoprotein A-I (apolipoprotein A-I value $<$ th percentile despite a normal serum concentration of HDL cholesterol) in almost one third of the normolipidaemic patients with coronary artery disease. Reduced plasma concentrations of apolipoprotein A-I have been noted in the first degree relatives of patients with coronary heart disease ${ }^{3637}$ including their children, ${ }^{38}$ implying that this syndrome too has a genetic basis. In addition, environmental factors can influence plasma concentrations of $\underset{\vec{s}}{\vec{F}}$ apolipoprotein A-I; physical inactivity, ${ }^{39}$ smoking, ${ }^{40} \frac{\vec{\sigma}}{\partial}$ and $\beta$ blockers ${ }^{41}$ all tend to reduce them. In the $\frac{\bar{O}}{}$ present study plasma concentrations of $\frac{\overline{\bar{D}}}{\bar{\sigma}}$ apolipoprotein A-I remained significantly lower in $\mathbb{Q}$ patients with coronary artery disease than in the controls, even when the influence of smoking and $\beta$ blockers was taken into account.

Except for one small prospective study of $\overrightarrow{\vec{J}}$ apolipoprotein $\mathrm{A}-\mathrm{I}^{12}$ it remains to be established whether measurement of apolipoproteins can help to predict the risk of coronary heart disease. Analysis of restriction fragment length polymorphism of $O$ apolipoprotein genes may, however, help to define the usefulness of serum apoprotein assays as indices of genetically determined coronary disease, especially in normolipidaemic individuals.

This work was supported in part by the British Heart Foundation. We are grateful to Professor A Maseri, Dr C Oakley, Dr G Davies, and Mr R Sapsford for enabling us to study patients under their care, to the BUPA Medical Centre for providing data and samples, and to Mr D Robinson for undertaking some of the statistical analyses. DW and I T were supported by a grant from BUPA Medical Research.

\section{References}

1 Thompson G. Apoproteins: determinants of lipoprotein metabolism and indices of coronary risk. Br Heart J 1984;51:585-8.

2 Brunzell JD, Sniderman AD, Albers JJ, Kwiterovich PO. Apoproteins B and A-I and coronary artery disease in humans. Arteriosclerosis 1984;4:49-83.

3 Schmidt SB, Wasserman AG, Muesing RA, et al. Lipoprotein and apolipoprotein levels in angiographically defined coronary atherosclerosis. $\mathrm{Am} \mathrm{J}$ Cardiol 1985;55:1459-62.

4 Reardon MF, Nestel PJ, Craig IH, Harper RW. Lipoprotein predictors of the severity of coronary artery disease in men and women. Circulation 1985; 71:881-8.

5 Hamsten A, Walldius G, Stamosi A, Dahlen G, de Faire U. Relationship of angiographically defined coronary artery disease to serum lipoproteins and apolipoproteins in young survivors of myocardial infarction. Circulation 1986;73:1097-110.

6 Kukita H, Hamada M, Hiwada K, Kokubu T. Clinical significance of measurement of serum apolipoprotein A-I, A-II and B in hypertriglyceridemic male patients with and without coronary artery disease. Atherosclerosis 1985;55:143-9.

7 Durrington PN, Hunt L, Ishola M, Kane J, Stephens WP. Serum apolipoproteins AI and B and lipoproteins in middle aged men with and without previous myocardial infarction. Br Heart J 1986;56:206-12.

8 Sedlis SP, Schechtman KB, Ludbrook PA, Sobel BE, Schonfield G. Plasma apoproteins and the severity of coronary artery disease. Circulation 1986;73:978-98. 
9 Kottke BA, Zinsmeister AR, Holmes DR, et al. Apolipoproteins and coronary artery disease. Mayo Clin Proc 1986;61:313-20.

10 Warnick GR, Albers JJ. A comprehensive evaluation of the heparin-manganese precipitation procedure for estimating high density lipoprotein cholesterol. $J$ Lipid Res 1978;19:65-76.

11 Friedewald WT, Levy RI, Fredrickson DS. Estimation of the concentration of low-density lipoprotein cholesterol in plasma, without use of the preparative ultracentrifuge. Clin Chem 1972;18:499-502.

12 Manual of Laboratory Operation, Lipid Research Clinics Program. Lipid and Lipoprotein Analysis, Vol I 1974; DHEW publication no (NIH) 75-628.

13 Sniderman A, Teng B, Terry M. Determination of B protein of low density lipoprotein directly in plasma. $J$ Lipid Res 1975;16:465-9.

14 Havekes L, Hemmink J, de Witt E. Low density lipoprotein apoprotein B in plasma as measured by radial immunodiffusion and rocket immunoelectrophoresis. Clin Chem 1981;27:1829-33.

15 Warnick GR, Benderson JM, Albers JJ. Dextran sulfate and $-\mathbf{M g}^{2+}$ precipitation procedure for quantitation of high density lipoprotein cholesterol. Clin Chem 1982;28:1379-88.

16 Shaper AG, Pocock SJ. British blood cholesterol values and the American consensus. Br Med J 1985;291: 480-1.

17 Warnick GR, Nguyen T, Albers AA. Comparison of improved precipitation methods for quantification of high density lipoprotein cholesterol. Clin Chem 1985; 31:217-22.

18 Teng B, Sniderman AD, Soutar AK, Thompson GR. Metabolic basis of hyperapobetalipoproteinemia. Turnover of apolipoprotein B in low density lipoprotein and its precursors and subfractions compared with normal and familial hypercholesterolemia. J Clin Invest 1986;77:663-72.

19 Rifai N, King ME. Immunoturbidometric assays of apolipoproteins A, AI, AII, and B in serum. Clin Chem 1986;32:957-61.

20 Patterson D, Slack J. Lipid abnormalities in male and female survivors of myocardial infarction and their first degree relatives. Lancet 1972;1:393-9.

21 Goldstein JL, Hazzard WR, Schrott HG, Bierman EL, Motulsky AG. Hyperlipidemia in coronary heart disease. I. Lipid levels in $\mathbf{5 0 0}$ survivors of myocardial infarction. J Clin Invest 1973;52:1533-43.

22 Lewis B, Chait A, Oakley CMO, et al. Serum lipoprotein abnormalities in patients with ischaemic heart disease: comparisons with a control population. Br Med J 1974;ili:489-93.

23 Martin MJ, Hulley SB, Browner WS, Kuller LH, Wentworth D. Serum cholesterol, blood pressure and mortality; implications from a cohort of 361,662 men. Lancet 1986;13:933-6.

24 Consensus Development Conference on Lowering Blood Cholesterol to Prevent Heart Disease. JAMA 1985;253:2080-6.

25 Hulley SB, Rosenman RH, Bawol RD, Brand RJ. Epidemiology as a guide to clinical decisions. The association between triglyceride and coronary heart disease. N Engl J Med 1980;302:1383-9.

26 Bottiger L-E, Carlson LA. Risk factors for ischaemic vascular death for men in the Stockholm Prospective
Study. Atherosclerosis 1980;36:389-408.

27 Castelli WP. The triglyceride issue: a view from Framingham. Am Heart $J$ 1986;112:432-7.

28 Ordovas JM, Schaefer EJ, Salem D, et al. Apolipoprotein A-I gene polymorphism associated with premature coronary artery disease and familial hypoalphalipoproteinemia. N Engl J Med 1986;314: 671-7.

29 Castelli WP, Doyle JT, Gordon T, et al. HDL cholesterol and lipids in coronary heart disease. The cooperative lipoprotein phenotyping study. Circulation 1977;55:767-72.

30 Yaari S, Goldbourt U, Even-Zohar S, Neufeld HN. Associations of serum high density lipoprotein and total cholesterol with total, cardiovascular and cancer mortality in a 7-year prospective study of 10000 men. Lancet 1981;i:1011-5.

31 Shaper AG, Pocock SJ, Walker M, et al. Risk factors for ischaemic heart disease: the prospective phase of the British Regional Heart Study. J Epidemiol Community Health 1985;39:197-209.

32 Pocock SJ, Shaper AG, Phillips AN, Walker M, Whitehead TP. High density lipoprotein cholesterol is not a major risk factor for ischaemic heart disease in British men. Br Med J 1986;292:515-9.

33 Sniderman AD, Wolfson C, Teng B, Franklin FA, Bachorik PS, Kwiterovich PO. Association of hyperapobetalipoproteinaemia with endogenous hypertriglyceridaemia and atherosclerosis. Ann Intern Med 1982;97:833-9.

34 Cambien F, Warnet JM, Jacquelson A, Dulcimetiere $P$, Richard JL, Claude JR. Relation of parental history of early myocardial infarction to the level of apoprotein B in men. Circulation 1987;76:266-71.

35 Sniderman AD, Teng B, Genest J, Cianflone $K$, Wacholder S, Kwiterovich PO. Familial aggregation and early expression of hyperapobetalipoproteinemia. Am J Cardiol 1985;55:291-5.

36 Kukita H, Hiwada $\mathbf{K}$, Kokubu T. Serum apolipoprotein A-I, A-II and B levels and their discriminative values in relatives of patients with coronary artery disease. Atherosclerosis 1984;51: 261-7.

37 De Backer G, Hulstaert F, de Munck K, et al. Serum lipids and apoproteins in students whose parents suffered prematurely from a myocardial infarction. Am Heart J 1986;112:478-84.

38 Freedman DS, Sriniivasan SR, Shear CL, Franklin FA, Webber LS, Berenson GS. The relation of apolipoproteins A-I and B in children to parental myocardial infarction. $N$ Engl J Med 1986;315:721-6.

39 Nikkila EA, Kuusi T, Myllynen P. High density lipoprotein and apolipoprotein A-I during physical inactivity. Atherosclerosis 1980;37:457-62.

40 Berg K, Borresen A-L, Dahlen G. Effect of smoking on serum levels of HDL apoproteins. Atherosclerosis 1979;34:339-43.

41 van Brummelenn $P$. The relevance of intrinsic sympathomimetic activity for $\beta$ blocker-induced changes in plasma lipids. J Cardiovasc Pharmacol 1983;5 (suppl 1):551-5.

42 Ishikawa $\mathrm{T}$, Fidge N, Thelle DS, Forde $\mathrm{OH}$, Miller NE. The Tromso Heart Study: serum apolipoprotein AI concentration in relation to future coronary heart disease. Eur J Clin Invest 1978;8:179-82. 